\title{
The Effectiveness of Industry-Based Approach (I-BA) in the Productive Subject of Entrepreneurship for Vocational High School Students
}

\author{
V. Lilik Hariyanto \\ Universitas Negeri Yogyakarta \\ Yogyakarta, Indonesia \\ lilik_hariyanto@uny.ac.id
}

\begin{abstract}
The objectives of this study are: (1) to produce an effective learning model using Industry-Based Approach (I-BA) for the productive subject of entrepreneurship, namely the subject of Furniture Engineering (2) to develop a guidebook for the implementation of the developed learning model, (3) to generate a learning module for the implementation of the developed learning model.The method of this study referred to the model of Research and Development from Borg \& Gall, which consisted of: (1) Research, to collect data about the products to be developed, (2) Development, to analyze the product through classroom learning. This study was conducted at SMK Pangudi Luhur, Muntilan, Magelang, Central Java. The subjects of this study were the students of the program study of Furniture Engineering. The data was analyzed by using descriptive statistical analysis. The results of this study were: (1) a learning model using Industry-Based Approach (I-BA) for the productive subject of entrepreneurship, namely the subject of Furniture Engineering which was assessed as effective, (2) a guidebook for the implementation of the developed learning model (3) a learning module for the implementation of the developed learning model.
\end{abstract}

Keywords - enterpreneurship; learning model; Industry-Based Approach (I-BA Model)

\section{INTRODUCTION}

Implementation of education in vocational hign schools is a form of vocational education which intergrates systematically education programs in schools and skill acquisition programs achieved through hands-on working in workplaces. Through this concept, students experience learnings in two places, school and industry. This system is an implementation of mitch and match concept [1]. Nevertheless, that vocational school students or graduates are considered skillful does not guarantee that they success in entepreneurship implementations, since they feel inferior and lack of confidence. This happens as students are not capable to elaborate their skills achieved from learning and their enterpreneurial skills, a product of such a current partial learning.

Facts reveal that in SMK in the field of Technology and Engineering Expertise in the Curriculum 2013 group B (compulsory), Enterpreneurship and group C2 (specialization), basics of skill program (productive), in reality, often run separately [2];[3];[4];[5]. Such partial learning pattern contributes to the difficulties in realizing the success of the objectives of vocational education in schools, especially Enterpreurship subject which prepares graduates as independent enterpreneurs.

Ideally, the spirit of intergrated learning between productive practice subjects and industry-based Enterpreurship subject can produce students or graduates with a staunch enterpreneurship, even have the capabilities to create new workfields for people. This is supported with Curriculum 2013 implemented in some SMKs with the obligation of possessing complete equipment and infrastructure. Support coming from goverment is by issuing a holding assistance policy Program Pendidikan Kecakapan Wirausaha (PKW) [6]. Minister of Cooperatives, Small and Medium Enterprise Indonesia states that enterpreneurial programs in SMK need to always reform. Data revelas that the ratio of Indonesian enterpreneurs in 2013/2014 stand at 1,67\%, now according to Badan Pusat Statistik (Central Bureau of Statistics), the persentage increases at $3,1 \%$. Nevertheless, until recently, the number of Indonesian enterpreneurs has not reached the ideal number, $2 \%$ out of total number of Indonesian citizens [7]. Current data from Global Entrepreneurship Monitor (GEM) shows that Indonesia owns around $1,65 \%$ enterpreneurs from 250 population. The implementation, however, has not come up with a valid and realiable model of enterpreneurial learning which can be regularly choosen as the alternative learning model and be applied in learnings, commonly in senior high schools and especially in SMKs which creates the new-born independent enterpreneurs. Through this research, a learning model oriented on the development of industry-based enterpreneurship competencies, further called as IndustryBased Approach learning model (I-BA Model).

The focus of the problems are formulated as follows: (1) How to create I-BA Model in effective enterpreneurial Productive Subject of Furniture Technique Practice? (2) How to create a guidebook of I-BA Model implemenation in effective enterpreneurial Productive Subject of Furniture Technique Practice?, (3) How to create a learning modul for I-BA Model implemenation in effective enterpreneurial Productive Subject of Furniture Technique Practice?

Vocational education prioritizes student's capabilitiy development to carry out particular jobs Reference [7] was about National Education System that defines vocational 
education as an education that prepares students to be able to work in specific fields. Reference [8] defines "Vocational education as an education that provides supplies to the students for learning a living". Moreover The United Congress defines "Vocational education as organized educational programs which are directly related to the preparation of individuals for paid or unpaid employment, or for additional preparation for a career require other than a baccalaureate of advanced degree". Meanwhile vocational education held by Ministry of Education and Culture is a professional education path equivalent to industry education and training set up by other education holders or workspaces. An orientation of vocational education is to prepare the graduates to be able to become independent enterpreneurs with their possession of specialized knowledge learned.

The success of enterpreneurial education does not pinned down to the number of graduates produced, but it leads more to its enterpreneurial achievement development. In relation to this finding, Gibb in [9] outlines three objectives that should be considered: (1) providing students with deep understandings about enterpreneurship in terms of function, role, and contribution to keep abreast of modern economic development, (2) teaching students some success enterpreneurship models on how to run bussiness, started from the commitment to put efforts to pursue the goal with certain ways, (3) teaching students how to be enterpreneurs with the steps to start and to manage their own business. The point is that the approach of learning enterpreneurship is by action or experiential based learnings [10]. Action learning principles focus on the real activities. Therefore, these does not only depend on the acquired experiences but also tend to carry out actions based on the strong knowledge mastery. This approach is frequently adopted by schools as the foundation of enterpreneurial education development. One of the model design is presented below.

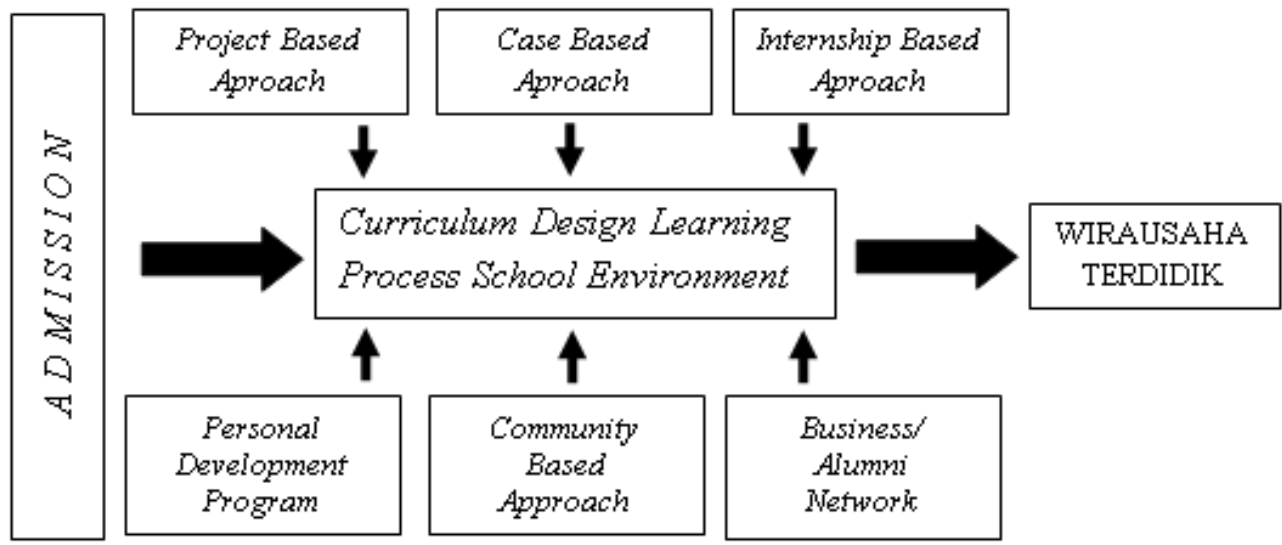

Fig 1. Model of Enterpreneurship Education S1 BPMB School

Enterpreneurship education is impossible observed from mere knowledge master, but more than an artistical skill capability. It is learned comprehensively, from cognitive, affective, and psychomotoric aspects in the classroom. Student activities are directed to experiential prosessess. Therefore, the appropriate enterpreneurship education model, in this case, is experiential learning model. Experiential learning forms human's experiential learning cycle which is divided into 4 cycles [11]. As individuals achieve new experiences (concrete experience), they will compare their own new experiences to others' (observational and relections). Further, the individuals will think about it, form new pattern leading to conclusions and then generate a new concept (formation of abstract conncepts and generalizations). That is the way the cycle works, if it is well conducted it will make a decision and an action closed to the truth.

Concrete experiences in industries (workplace), experienced both individually or collectively, are good teachers. Those experiences, however, are not enough to be achieved just they way things are, for that responds are needed. This remains understood since learning activities which are based on workspace experiences are designed in order that students experience the processes as the real enterpreneurs. The experiences are then put in deep thoughts, reflected systematically, and interconnected to enterpreneurship theories. As the result, they shape novel concepts and tips to practice after graduating from school. For that reason, a cooperation is needed between educational institutions and relevant business industries. The cooperations include: (1) industrial work practice, (2) graduate distribution, (3) student competence test, (4) learning facilities and infrastuctures, (5) learning program. These are in accordance with [12]. statement that to prepare work experiences as a part of vocational education demands the industry/business world to be involded in the planning, execution, and assessment of the vocational education programs. This pattern is a dual education system, as a form of industrial education embedded in industry-based school learning programs for achieving a professional level [13]. In some SMKs, it is known as teaching factory. The strengths cover (1) learning focused on customer' 
satisfaction based on market realities, objectivity, and quality, (2) effective objective achievement to be trusted, unarguable, proactive, with inndustry as its core, (3) learning benchmarks is the best productivity in industrial projects, (4) competitive leaning as the result of real understandings from possessing high commitment, (5) leading to best learning rest on proactive attitude for changing, more options, business practice breakthrough, and best performance. While the weaknessess are: (1) function of learning becomes not optimal because of profit oriented, (2) institutional organizations do not walk together with educational institutions [14].

A practice of teaching factory is developed by NYPi Nanyang Polytechnic International [15]. It adopted learning developments in hospitals.

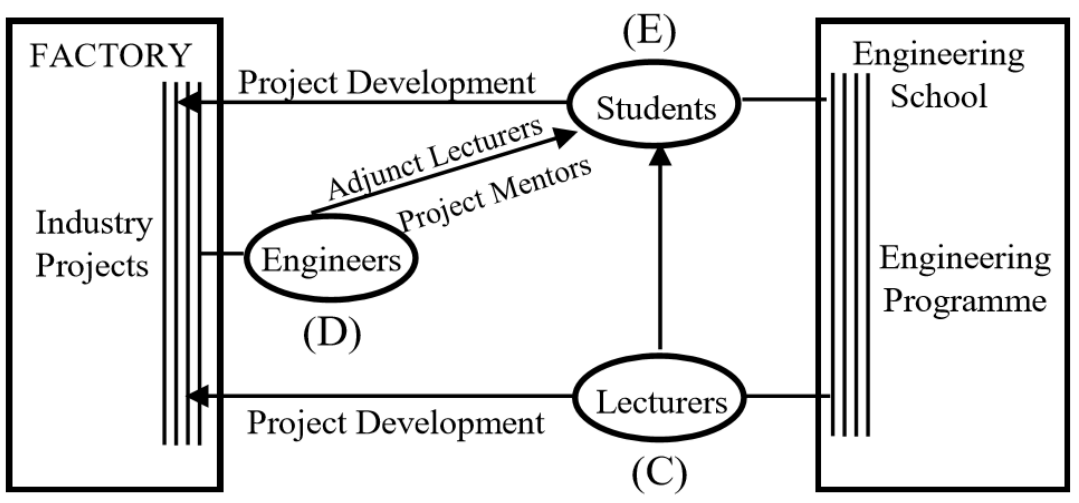

(B)

(A)

Fig 2. Replication of Teaching Hospitals Concept for Engineering Education

The replication was then developed into a concept of teaching factory displayed in Figure 3 below.

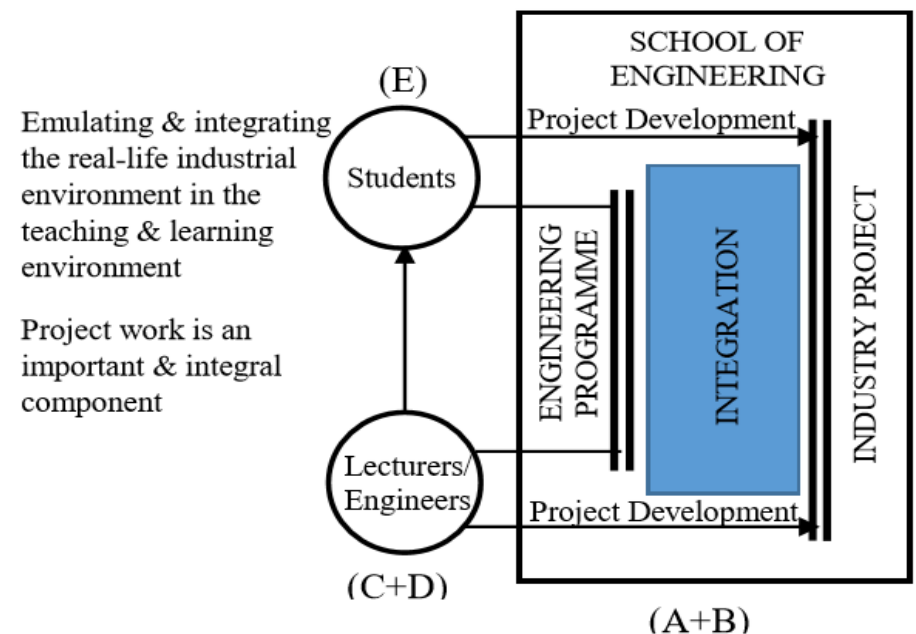

Fig 3. Teaching Factory Concept

The developing of I-BA has concerns on the enterpreneurial character building for SMK students in Furniture Programme, namely (1) internalizing the spirit and values of enterpreneurship, (2) creating project products relevant with workspace growths and later on marketing the products, (3) graduates are expected to support their lives independently and the creation of workfields.

The development employs a model development approach by [16], the components consist of: (1) syntax, (2) social system, (3) reaction principles, (4) support system, (5) instructional impacts and (6) accompaniment impacts. I-BA Model connects three learning materials, Enterpreneurship subject and Furniture Practice subject which are based on an approach to the growth of furniture industries. The implementation is quite similar to the reality and everyday life experience. Teacher's role focuses on the learning management, done for the sake of the goal that students, in the 
process of learning, can discover their own knowledge not from teacher's information.

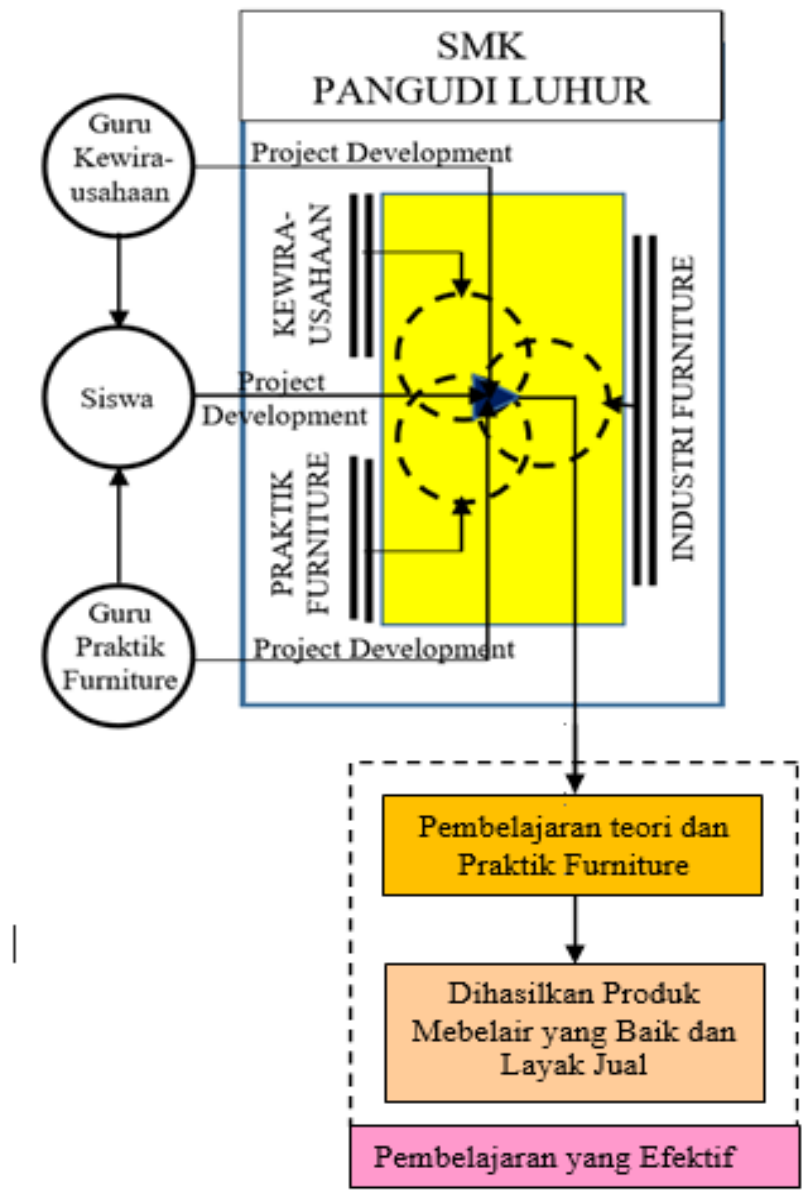

Fig 4. Effective I-BA Learning Model

The structure of this I-BA Model can be implemented in odd or even semester in SMK with Block-Model learning. The intergrated learning materials between the subjects of Enterpreneurship and Furniture Practice are given in the form of modul. The number of meetings should meet the effective week schedule in SMK.

The essense of effective learning, besides learnersoriented, also focuses on how learnings give understandings, change behaviours, and are able to be implemented in life comprehesively to the students. Characteristics of effective learning according to [17] are: (1) student-centered, (2) educational interaction, (3) teacher-student, (4) democratic, (5) variative methods, (6) beneficial learning material, (7) condusive environment, (8) supportive learning atmosphere. In the other hand, Reference [15] assert that effective teaching is teachinng students on how they acquire teacher's information as their owns. Moreover, Trianggoro (2013) mentions some characeristics of effective teachers, such as (1) have interest in learning subject, (2) have the ability to interprate student psychology, (3) grow learning spirit, (4) have the imagination to explain, (5) possess learning methods/strategies, (6) welcome to all students. Thus, effective learners can be defined as learners who perceive teacher's information through optimalizing the existing learning resources.

With regard to the effectiveness of learning, to achieve it one of the learning aspects to consider is model and or method used in learning. In this model, the new paradigm of instructional effectiveness requires teachers to change the outlook on learning; not just giving lectures but rather focusing on creating new experiences for students. Utilization of learning technology has popularized, hence the growth of industrial world and business world as learning sources need to be integrated in order to achieve the effective learning process. Learning will work effectively if the information from learning resources existed in industrial and business world such as: material selection, work and industrial products management, and so forth can be absorbed by students. So the meaning of the effectiveness of learning model, in this case includes: (1) teacher activites in classroom learning, (2) student activities in the learning, (3) teacher ability in applying models of learning, (4) teacher responses to the application of learning model and (5) student responses to the application of learning model. 


\section{RESEARCH METHOD}

This research study belongs to Research \& Development, with product development orientation. The development process is accurately conducted and the final product is evaluated. Reference [18] states that Research and Development creates products. For this research, the product was an intergrated enterpreneurship learning model, called as I-BA Model.

The study was located in SMK Pangudi Luhur, Muntilan, Magelang, Central Java, which has Furniture Technique Study Program. Grade XI participated as the research subject.

The developing procedure of I-BA Model was started by preliminary study on the research problems, review of relevant literatures, and context analysis where the program to be implemented. This phase covered the stages of investigation and information gathering, mainly that related to current enterpreneurship learning in SMK and work competencies required by the workspace. The object of the research was vocational high schools and higher education institutions with high-quality enterpreneurship learning activities compared to other educational institutions in Special Region of Yogyakarta and surroundings.

Identifications of entrepreneurial work competencies can be obtained from business needs analysis. This information is obtained through DACUM (Developing a curriculum) workshop. Reference [19] says that DACUM approach is particularly suitable in designing curriculum contents, for educational and training institutions that implement or plan to implement Competency-Based Education (CBE) or Performance-Based Training (PBT).

The development of the I-BA Model was based on the Standards of Competence and Basic Competences developed by Badan Standar Nasional Pendidikan (BSNP) Kementerian Pendidikan Nasional (the National Education Standards Agency of the Ministry of National Education). The competency achievement indicators were developed from the national syllabi and combined with the competency profiles generated from DACUM analysis. The result of the DACUM determination would be the basis for: (1) arrangement of lesson plan (known as Rencana Pelaksanaan Pembelajaran),
(2) learning materials in the form of entrepreneurship learning modules. Meanwhile, to filter information on entrepreneurship learning situations in schools, besides document review (curriculum and teaching materials), in-depth interviews, and direct observation in schools, focus group discussion (FGD) was held with entrepreneurship teachers, heads of study programs and heads of SMK for Curriculum Affairs in the cities of Yogyakarta Special Regency. The purpose of FGD with teachers was to discuss DACUM profile resulted from DACUM workshops and developing plans of entrepreneurship learning models and learning needs in schools. The results of business competency needs analysis (DACUM competency profile) and learning needs analysis in the schools become the basis for I-BA instructional/learning development.

Research instruments used: (1) observation sheet of teacher and student activities in learning, used as a guideline to observe teacher and student behaviors during the learning process, (2) observation sheet of teacher ability to apply I-BA model in learning, aimed to obtain data about teacher ability in managing learnings through observation at the time of the learning activities take place, (3) questionnaire of of teacher and student responses as a mean to express feelings, opinions, and comments on the learning activities.

Data analysis techniques were conducted descriptivelyqualitatively by providing logical narratives in accordance with research objectives. The accuracy reflected how far that the designed instrument measured the created products. The effectiveness analysis was based on descriptive analysis reffering to normative calculation analysis with norm reference [20].

\section{RESULTS AND DISCUSSIONS}

The result of excavation of entrepreneurial work competencies required for the business world through DACUM (Developing a curriculum) approach was in the form of competencies of learning needs in schools combined through a Focus Group Discussion (FGD) activity resulted in the scope of I-BA Model Furniture Practice material structures.

TABLE 1.STRUCTURE OF FURNITURE PRACTICE I-BA MODEL MATERIAL

\begin{tabular}{|c|c|}
\hline Materials & Products \\
\hline - Furniture Theory & \multirow{7}{*}{$\begin{array}{l}\text { Clothes hanger board, } \\
\text { Newspaper box, Chair, Wood waste use }\end{array}$} \\
\hline - Industrial Work Practice & \\
\hline - Refill & \\
\hline - Furniture Technical Design & \\
\hline - Furniture Practice with Hand Tools & \\
\hline - Furniture Construction & \\
\hline - Finishing Furniture & \\
\hline
\end{tabular}

The learning stages during the research are presented in the Table below. 
TABLE 2. SCHEDULES OF FURNITURE PRACTICE IN SMK PANGUDI LUHUR

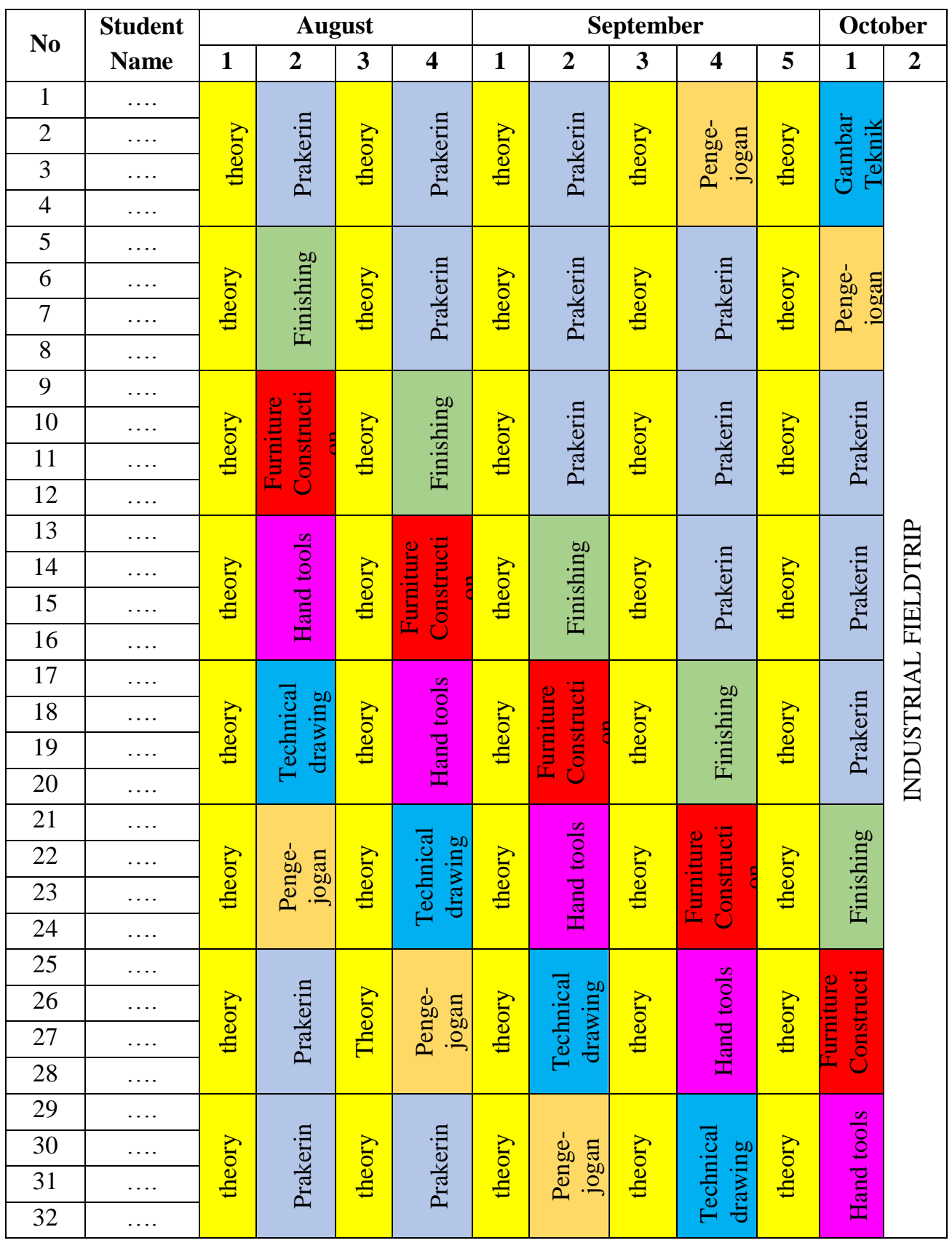

The effectiveness of the model is investigated from both teacher and student activities measured with the following indicators: (1) accuracy of I-BA Model based on the aspects of: (a) I-BA Model implementation as a learning model to prepare students for enterpreneurship, (b) learning modul to help students' understandings of the given materials, (c) lesson plan to unleash the implementation of I-BA Model, (d) assessment tool to evaluate what is necessary, (2) consistency from the aspects of: (a) learning modul provides consistent learninng outcomes, (b) learning evaluation provide consistent learning outcomes, (3) objectivity, based on aspects: (a) fun learning I-BA Model, (b) I-BA Model give students motivation (c) I-BA Model give opportunities for students to conduct self-exploration in enterpreneurship, (d) I-BA Model answers one of Vocational High School goals, that is enterpreneurship, (4) practicality, based on aspects: (a) task suitabilities with the pre-determined competencies, (b) obstacles in completing tasks, (c) comprehensible learning modul, (d) completed work results, and (5) language use, the use of Bahasa Indonesia which is: (a) proper, (b) communicative, (c) understandable, and (d) well structured sentences.

From those aspects, there are 18 aspects to measure. Therefore, the minimal score is 18,00 and the maximum score is 72,00 . It is obtained that normative average (Xnor) $=45,00$ 
and normative standard deviation (SDnor) $=9,00$. The criteria of effectiveness categories is classified as follows

TABLE 3. CRITERIA LIMIT OF EFFECTIVENESS CATEGORY SCORES BASED ON TEACHER'S ACTIVITIES

\begin{tabular}{|l|c|c|l|}
\hline No & Criterion & Conversion Score Scale 100 & \multicolumn{1}{|c|}{ Category } \\
\hline 1 & $\geq 58,50$ & $\geq 81,20$ & Very effective \\
\hline 2 & $45,00<58,50$ & $62,50<81,20$ & Effective \\
\hline 3 & $31,50<45,00$ & $43,75<62,50$ & Quite Effective \\
\hline 4 & $<31,50$ & $<43,75$ & Less Effective \\
\hline
\end{tabular}

From the instrument of Enterpreneurship teacher and productive teacher assessment, the result of factual averages were: (1) Score at beginning of semester before using I-BA model $=42,38$ with a conversion score of 58,91 (effective enough), and (2) Score at the end of semester after implementation of I-BA Model $=56.45$ with a conversion of 78.46 (effective). So in this case, it can be said that the implementation of I-BA Model, according to the teacher, can improve the effectiveness of student learning at $33.20 \%$.

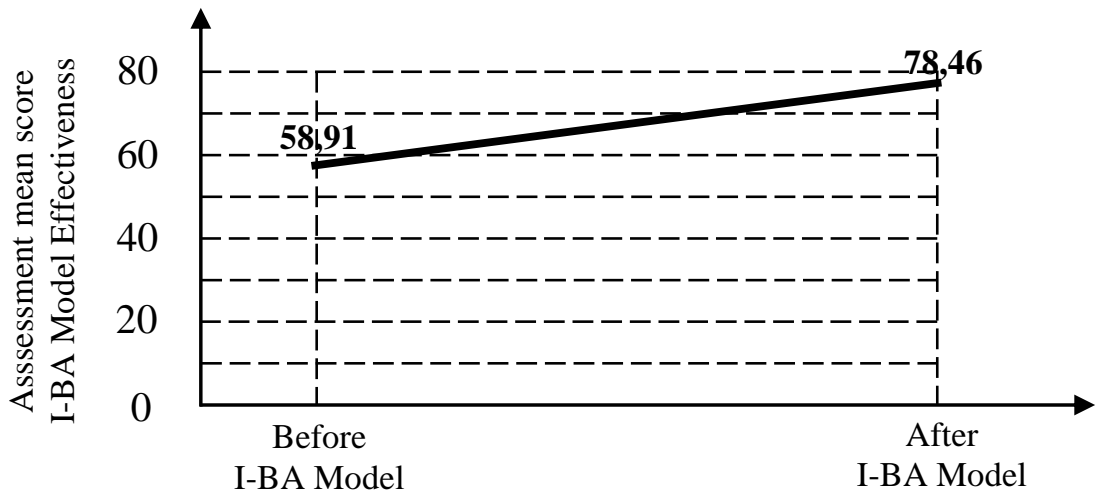

Fig 5. Diagram of the Assessment of I-BA Model Effectiveness from Teacher Aspect

Meanwhile, from the assessment instruments from 32 students, the factual averages showed: (1) Score at beginning of semester before using I-BA model $=46,47$ with a conversion score of 64,59 (effective) and (2) Score at the end of semester after implementation of I-BA Model $=54,14$ with a conversion of 75,25 (effective). In other words, from students' points of view the I-BA implementation can step up the effectiveness of student learning at $16,51 \%$.

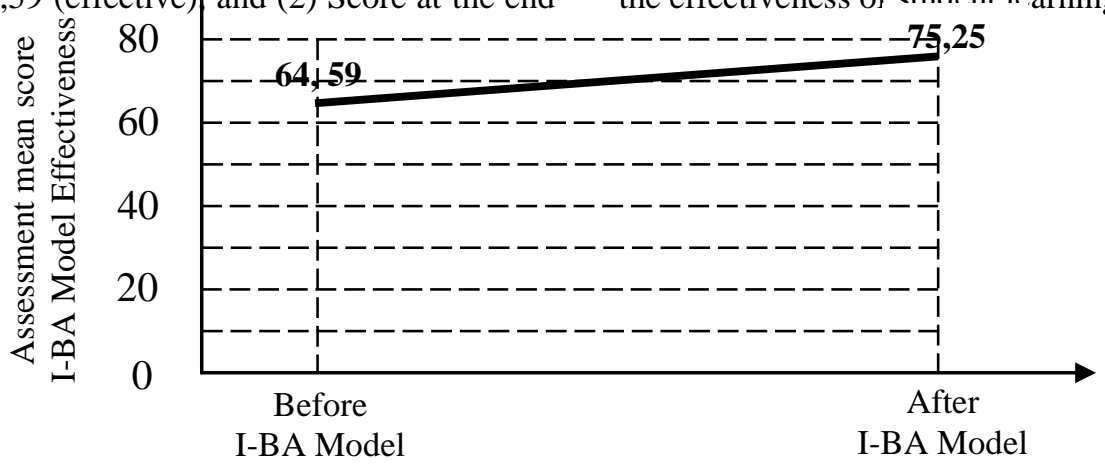

Fig 6. Diagram of the Assessment of I-BA Model Effectiveness from Student Aspect

The effectiveness of teacher's ability in managing learning is seen from the implementation of I-BA Model which is elaborated into some indicators as follows: (1) common accomplishments, outlined in aspects of: (a) the spirit of carrying out learnings with I-BA Model, (b) students learn with enthusiasm, (c) learning always begin with saying prayer together, (d) teachers always conduct learning apperception, (e) teachers encourage student's motivation while learning, (f) sharings between teacher-students about basic competence in achieving the learning goal, (g) sharings between teacherstudents on the achievement indicators of the learning goal, (h) sharings between teacher-students on the learning achievement evaluation criteria; (2) planning and objectives, elaborated in some aspects: (a) learning objectives have been completed, (b) lesson plans are always executed in detail, (c) delivering materials is done well, (d) learning schedules are provided in detail, (f) students' activities have been arranged before, (g) instructional time allotment is adequate; (3) 
interaction, including aspects of: (a) discussion about learning materials within students runs in dinamic, (b) students are encouraged to express their ideas, (c) students are encourage to ask in learning, (d) teacher give solutions to the unsolved problems faced by students, (e) teacher and students draw up the results of discussion together; (4) learning materials, covering some aspects: (a) learnings are implemented as planned, (b) delivery of material contents is complete, (c) practice materials are linked to enterpreneurial competency commands; (5) reading materials, involving the aspects of: (a) optimal use, (b) stimulation for further reading, (c) intergrated reading comprehension; (6) tasks: (a) assist students to comprehend learning materials, (b) stimulate students to access further reading resources, (c) embody in learning; (7) assessment / evaluation: (a) assessment done periodically by teacher, (b) feedback always be given, (c) assessing based on the guidelines, (d) results of teacher assessment reflect the students' actual performances, (e) results of teacher assessment reflects its learning indicators; (8) teacher, (a) feeling enthusiastic while teaching, (b) the actions remain dinamic and energetic, (c) thowing jokes or healthy humors, (d) possessing attractive ways of teaching, (e) delivering clear explanations, (f) having good preparations, (h) giving summaries about the topic discussed, (i) putting the good/right voice stresses while teaching; (9) language use, the implementation uses Bahasa Indonesia which is (a) proper, (b) communicative, (c) comprehensible, (d) well-structured.

From the descriptions, there are 46 aspects to measure. Therefore, the minimal score is 46,00 and the maximum score is 184,00 . It is obtained that normative average (Xnor) $=$ 115,00 and normative standard deviation (SDnor) $=23,00$. The criteria of effectiveness categories is classified as follows.

TABLE 4. CRITERIA LIMIT OF EFFECTIVENESS CATEGORY SCORES BASED ON MANAGEMENT

\begin{tabular}{|l|c|c|l|}
\hline No & Criterion & $\begin{array}{c}\text { Conversion Score } \\
\text { Scale 100 }\end{array}$ & \multicolumn{1}{|c|}{ Category } \\
\hline 1 & $\geq 149,50$ & $\geq 81,20$ & Very effective \\
\hline 2 & $115,00<149,50$ & $62,50<81,20$ & Effective \\
\hline 3 & $80,50<115,00$ & $43,75<62,50$ & Quite Effective \\
\hline 4 & $<80,50$ & $<43,75$ & Less Effective \\
\hline
\end{tabular}

Assessment of teacher's capability in classroom management, reviewed from the implementation of I-BA model through lesson plans (RPP) of Theory revealed that: (1) observation of assessment for RPP1 and RPP2 has an average score of 112,36 converted into average 61,07 (quite effective), (2) observation of assessment for RPP3 and RPP4 has an average score of 129,04 converted into average 70,13 (effective). Therefore, the increase of effectiveness of I-BA model stands at $14,84 \%$.

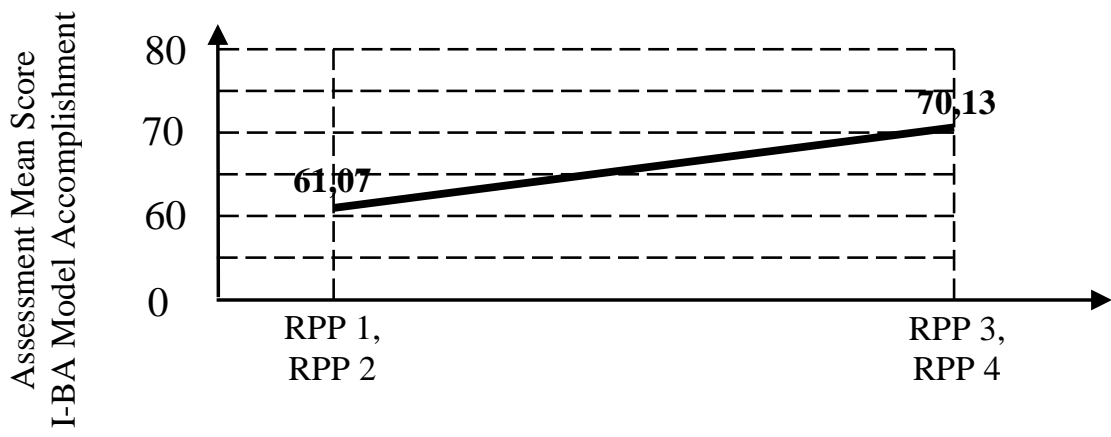

Fig 7. Diagram of the Assessment of I-BA Model Implementation in Classroom Learning

Teacher' activities in learning are measured based on some indicators, such as: (1) introduction, with aspects covering: (a) opening the class with saying a prayer together with students before starting the lesson, (b) giving apperception before the main activities, (c) introducing the learning competence to achieve, (d) encourage students to study diligently, (e) exxplaing the learning objectives, (f) preparing learning media; (2) main activities, such as: (a) explaining in details the topic of the lesson, (b) using modules suitable for the learninng materials, (c) providing time for students to study the related modules, (d) giving chances for students to discuss the materials, (e) giving chances for students to ask as they have difficulties in understanding the materials, (f) providing way-out solutions for learning problems faced by students, $(\mathrm{g})$ teaching in line with RPP, (h) giving feedbacks for the materials discussed, (i) organizing students, (j) correcting students' works, (k) reminding students as they make mistakes, (l) keeping the learning condusive, (m) utilizing media to support the delivery of materials; (3) closing, covering: (a) summarizing the lesson at the end of the meeting, (b) inviting students to ask about the materials that have not been well acquired, (c) suggesting to study materials for the next meeting, (d) closing the lesson with saying prayer together; (4) language use, teacher uses Bahasa Indonesia which is (a) proper, (b) communicative, (c) understandable, and (d) well structured sentences. 
From the descriptions, there are 27 aspects to measure. Therefore, the minimal score is 27,00 and the maximum score is 108,00 . It is obtained that normative average (Xnor) $=67,50$ and normative standard deviation (SDnor) $=13,50$. The criteria of effectiveness categories is classified as follows.

TABLE 5. CRITERIA LIMIT OF EFFECTIVENESS CATEGORY SCORES BASED ON TEACHER'S ACTIVITIES

\begin{tabular}{|c|c|c|l|}
\hline No & Criterion & $\begin{array}{c}\text { Conversion Score } \\
\text { Scale 100 }\end{array}$ & \multicolumn{1}{|c|}{ Category } \\
\hline 1 & $\geq 87,50$ & $\geq 81,20$ & Very effective \\
\hline 2 & $67,50<87,50$ & $62,50<81,20$ & Effective \\
\hline 3 & $47,25<67,50$ & $43,75<62,50$ & Quite Effective \\
\hline 4 & $<47,25$ & $<43,75$ & Less Effective \\
\hline
\end{tabular}

In such cases, teacher's activities in teaching with I-BA Model lead to the activities as mentioned in the above indicators. To observe the activities, the researcher assigned 4 university students to do the task. They observed the activities of both Enterpreneurship and productive subject teachers with the proportion of two observers for one productive subject teacher and two other observers for one Enerpreneurship teacher. The observation results for each lesson plan convey that RPP1 $=79,60$ with conversion score of 73,71 (effective); RPP2 = 85,39 converted into 79,06 (effective); RPP3 = 88,54 converted into 81, 98 (very effective); and RPP4 = 86,93 converted into 80,49 (effective).

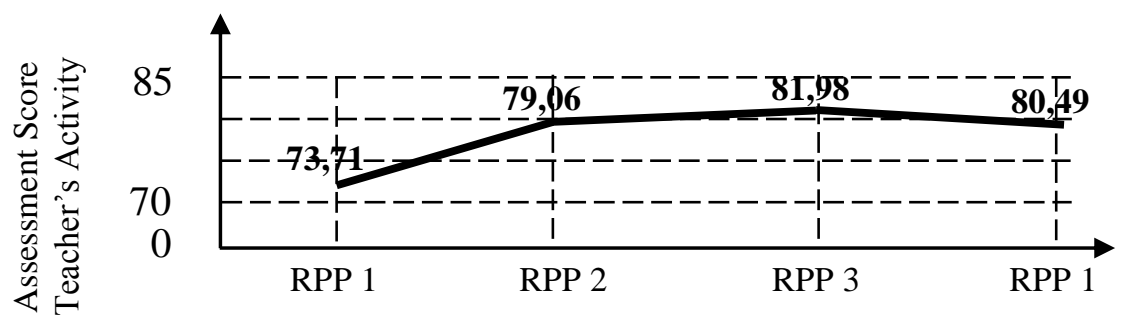

Fig 8. Diagram of Teacher's Activities Assessment I-BA Model

Students' activities in learning are measured based on these indictors: (1) student's concentration while learning, including (a) coming on-time, (b) sitting quietly, (c) listening to teacher's explanation seriously, (d) paying attention to teacher's activities in presenting the materials, doing asks seriously; (2) taking notes, including (a) teacher's notes written on the board, (b) teacher's oral explanations, (c) questions asked by students to the teacher, (d) teacher's answers regarding to the proposed questiones; (3) asking questions to teacher: (a) asking questions clearly, (b) asking questions which stimulate others' opinions, (c) asking tracker questions, (d) asking questions which encourage changes in cognitive levels; (4) answering teacher's questions, such as (a) answering comprehensively, (b) answering as what is asked, (c) competing to become the first to answer; (5) expressing ideas: delivering opinions as the reaction of teacher's explanation, (b) giving appreciation to the opinions of others, (c) giving constructive ideas for learning impovements; (6) language use: using Bahasa Indonesia which is (a) proper, (b) communicative, (c) understandable, and (d) well-structured sentences.

Student activity in this case, is an activity in following the learning which leads to such activities in the indicators mentioned above. The activity observers were 4 university students assigned by the researcher. They observed students in the lesson. The observation was principally aimed at class dynamics. One observer outlined a quarter of the total number of students. Here, a quater of them were put into a group of eight.

From the descriptions, there are 23 aspects to measure. Therefore, the minimal score is 23,00 and the maximum score is 92,00 . It is obtained that normative average (Xnor) $=57,50$ and normative standard deviation $($ SDnor) $=11,50$. The criteria of effectiveness categories is classified as follows

TABLE 6. CRITERIA LIMIT OF EFFECTIVENESS CATEGORY SCORES BASED ON STUDENTS' ACTIVITIES

\begin{tabular}{|c|c|c|l|}
\hline No & Criterion & $\begin{array}{c}\text { Conversion Score } \\
\text { Scale 100 }\end{array}$ & \multicolumn{1}{c|}{ Category } \\
\hline 1 & $\geq 74,75$ & $\geq 81,20$ & Very effective \\
\hline 2 & $57,50<74,75$ & $62,50<81,20$ & Effective \\
\hline 3 & $40,25<57,50$ & $43,75<62,50$ & Quite Effective \\
\hline 4 & $<40,25$ & $<43,75$ & Less Effective \\
\hline
\end{tabular}

Observation results on student activities for each lessons in RPP $1=71,42$ with conversion score of 77,84 (effective),
RPP $2=76,68$ with conversion score of 83,58 (very effective), RPP $3=78,72$ with conversion score of 85,80 (very effective), 
and RPP $4=78,56$ with conversion score of 85,63 (very effective). Schematically, the result is presented in the following graphic chart.

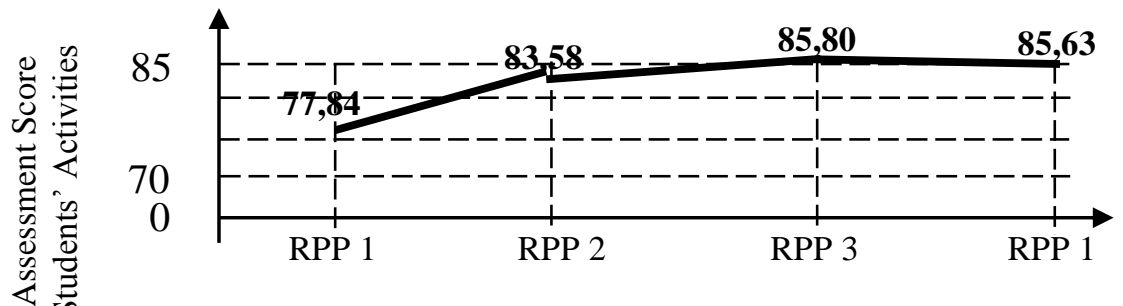

Fig 9.Diagram of Student Activities with I-BA Model Assessment

\section{CONCLUSION}

Regarding to the research results and discussions, it can be concluded that (1) I-BA Model was found in learning, employing the stages of Research and Development. The implementation reveals that (a) teacher' activities during the clasroom learnings increase the effectiveness at 33,20\%, (2) students' activities during the clasroom learning increase the effectiveness at $16,51 \%$, (c) teacher capabilities in the implementation of I-BA Model increase the effectiveness at $14,84 \%$, (d) teacher's responses on the implementation of IBA Model tend towards 'very effective', (e) students' responses on the implementation of I-BA Model tend towards 'very effective'; (2) learning media as a mean to implement IBA Model in the classroom can be developed, that is I-BA Model guidebook, (3) learninng modul as a mean to implement I-BA Model in the classroom can be developed, that is Enterpreneurship learning modul intergrated with Industrial Product-based Furniture Practice.

\section{REFFERENCES}

[1] Filosofi eksistensialisme dan esensialisme'. Retrieved at 9 October 2010, from http://kptk.weebly.com/indonesia.html.

[2] Marjuki, AhmadLaporan Observasi SMK Muhammadiyah Pakem Sleman. Yogyakarta: PTSP FT Universitas Negeri Yogyakarta. 2017.

[3] Afandi, Syahril. Laporan Observasi SMK Negeri 2 Yogyakarta. Yogyakarta: PTSP FT Universitas Negeri Yogyakarta. 2017.

[4] Sabbaha, Sakti Graha. Laporan Observasi SMK Negeri 2 Klaten. Yogyakarta: PTSP FT Universitas Negeri Yogyakarta. 2017.

[5] Martakim, Suhada. Laporan Observasi SMK Muhammadiyah Klaten. Yogyakarta: PTSP FT Universitas Negeri Yogyakarta. 2017.

[6] Ministry of Education and Culture. Permendikbud No 17 tahun 2017 tentang Petunjuk Teknis Bantuan Penyelenggaraan Program Pendidikan Kecakapan Kewirausahaan. 2017.

[7] Puspayoga, Anak Agung Gede Ngurah. Ratio Wirausaha Indonesia Naik Jadi 3,1 Persen. Accessed from www.depkop.go.id at 7 June 2017. 2017.
[8] Ministry of Education and Culture. PP No 29 tahun 1990, tentang: Pendidikan Menengah. Accessed from wordpress.com at 7 June 2017.2017.

[9] Finch, C.R., \& Crunkillton, J.R. Curriculum development in vocational and technical education, planning, content, and Implementation. 5 th ed. Boston: Allyn and Bacon. 1999.

[10] Soehadi, Agus W., Suhartanto, Eko, Winarto, V., \& Kusmolyono, M. Setiawan. Etrepreneurship education. Jakarta: Prastya Mulya Publishing. 2011.

[11]Hytti, U., \& O'Gorman. 'What is enterprise education? An analysis of the objectives and methods of enterprise education programmes in four European countries'. Education \& training. Vol. 6 (1), 11-23. 2004.

[12]Calsin M.C. Collaboration Vocational Education and Private Sector. Arlington: The American Vocational Association. 1984.

[13] Djojonegoro, Wardiman. Pengembangan sumber daya manusia melalui sekolah menengah kejuruan (SMK). Jakarta: PT Jayakarta Agung Offset. 1998.

[14] Hariyanto, V. Lilik. 'Pengembangan Model Pembelajaran Kewirausahaan Terintegrasi bidang Produktif siswa SMK Kompetensi Keahlian Teknik Konstruksi Batu dan Beton'. Disertation. Yogyakarta: Pasca Sarjana UNY. 2014.

[15]Nanyang Polytechnic International. Critical Success Factors a TVET Institution. 2016.

[16] Joyce, B., Weil, M., \& Calhoun, E. Models of teaching. USA: Pearson Education, Inc. (009.

[17]Borg, W.R, and Gall. M.D. Educational Research An Introduction. New York: Pitman Publishing Inc. 1989.

[18] Norton, R.E., \& Moser, J.R. DACUM (Developing a Curriculum), handbook (3th ed). Columbus: The Ohio State University. 2008.

[19] Azwar, SaifuddinTes prestasi fungsi dan pengembangan pengukuran prestasi belajar. Yogyakarta: Pustaka Pelajar Offset. 2013.

[20] Trianggoro, Choirul. Hakikat Pembelajaran Efektif. Accessed from www//: kampus/artikel at 7 June 2017. 2013. 